\title{
NOTES
}

\section{Etymology of the Term Mycoplasma}

\author{
CONRAD J. KRASS and MAX W. GARDNER \\ Department of Plant Pathology, University of California, Berkeley, California 94720
}

\begin{abstract}
The term mycoplasma apparently was first used by A. B. Frank in 1889 and then by Jakob Eriksson in 1897 to denote an intimate relationship between plant-invading fungi or other microorganisms and their host cells. Julien Nowak, in 1929, used the term taxonomically for the bovine pleuropneumonia organism. E. A. Freundt and D. G. Edward have since used the term mycoplasma in the classification of "pleuropneumonia-like" organisms. The original usage of the term to denote a cytological concept does not, however, affect the legitimacy of the subsequent taxonomic usage.
\end{abstract}

In recent years there has been a tremendous surge of interest in the group of organisms known as mycoplasmas. However, because little is known by most workers of the history of the name, we would like to discuss the origin of the term and how it has evolved. The term mycoplasma apparently was first used by A.B. Frank in 1889 (12). In a subsequent paper (13), he very explicitly defined the term.

Frank was concerned with the legume rootnodule organism, which he named Rhizobium leguminosarum (12). He thought it was a fungus rather than a bacterium, for he felt the "infection threads" of the organism were hyphae, and he knew of no hyphal-forming bacteria. Frank did state, however, that the hyphae were not typical and that the organism, because it lacked a cell wall, must be a myxomycete.

The "bacteroids" found within the nodules (isolated by treating the cells with $\mathrm{KOH}$ ) were thought to be legume metabolites, a concept popular at the time. The bacteroids were also found in above-ground parts of the plant, provided the root nodules were present. The bacteroids contained the micrococci of the nodule bacteria. They formed "Schwärmer" in hanging drops and multiplied rapidly in gelatin agar.

Frank (12), writing about invasion by means of infection threads, stated (translation): "The changed character of the protoplasm in the cortical cells arising from infection I will designate as mycoplasma, since it apparently arises from a mixture with a fungus-like organism." He wrote, in reference to nodule origin: ". . finally the mycoplasm filled meristem cells, out of which originates the bacteroid tissue."

Regarding the significance of the fungus element, Frank wrote (12): "Much more likely this cell content is a mixture of fungus and phanerogamic plasma, and its designation as mycoplasma may therefore appear justified. How we are to envisage this mixture is not yet decided. Optically the infection threads as well as the mycoplasma and cell nucleus appear homogeneous if the tissue is fresh and in water. Upon death of the tissue as a result of treatment, especially with reagents, e.g. in a potassium iodine-iodine solution, it is possible to make visible certain structures which are very likely the actual fungal constituent of the mixture."

Thus, Frank had defined mycoplasma as a mixture of fungal and plant protoplasm, stated that it gave rise to bacteroid tissue, and attempted to describe mycoplasma-filled cells (12). In his very extensive 1890 paper, Frank most explicitly defined mycoplasma as "fungusinfected protoplasm," "Mykoplasma d.h. pilzbehaftetes Protoplasma" (Frank's italics), and presented several illustrations of mycoplasma in pea cells (13).

Jakob Eriksson essentially laid the foundation for his misconceived mycoplasm theory in 1896 when he suggested that one source of the wheat rust fungus was from within the plant, especially early in the year (i.e., overwinters in the plant), although he did not use the term 
mycoplasma (4). In a series of three papers appearing in 1897 and 1898 Eriksson published, first in French, then in German, and finally in English, the results of his work on grain rusts wherein he gave a summary of rust species $(6,7)$, described formae speciales, and introduced the term mycoplasma $(5,6,7)$, which he described as follows: "The fungus lives for a long time a latent symbiotic life as a mycoplasma in the cells of the embryo and of the resulting plant, and that only a short time before the eruption of the pustules, when outer conditions are favorable, it develops into a visible state, assuming the form of a mycelium." Eriksson's theory was the subject of considerable controversy for several years until H. Marshall Ward, in a paper read before the Royal Society of London in 1903, effectively laid it to rest $(20)$. Ward convincingly demonstrated that Eriksson's "corpuscules spèciaux" were actually rust haustoria and suggested that Eriksson's misinterpretation of the structures may have been due to his methods of specimen preparation.

Eriksson refused to accept this and wrote a painstaking, rather critical, reply to Ward (8). $\mathrm{He}$ then published an extensive account concerning his mycoplasm hypothesis, including several illustrations of purported mycoplasma in host cells (11). In a later paper on the history of his theory, Eriksson stated that he used the word mycoplasma to describe the "internal disease source" (9).

Eriksson seemingly never abandoned his mycoplasm theory. In fact, in the second edition of his book (10), he extended the mycoplasm concept to include stages of potato wart, flax blight (about which he said: "The fungus spreads from cell to cell, and in the affected cells the plasmodium appears to contain protoplasm of the cell and of the fungus, and so may be regarded as 'Mycoplasm'."), late blight of potatoes, bean anthracnose, downy mildews, rusts, and even tobacco mosaic ("Other investigators favor a living infective material, 'contagium vivum fluidum,' closely bound up with the protoplasm of the cells (Beijerinck, 1898), forming a kind of 'mycoplasm' "). Eriksson came closest to being correct with this interpretation of tobacco mosaic and prompted E.C. Large to write (17): "Because of the great respect that was felt for Eriksson, the (mycoplasm) theory was discussed in nearly every paper on the Rust for many years, until finally it would have died of doubt, if some of those working on plant virus diseases had not then quietly borrowed it and added many embellishments." It is interesting to note that in none of his mycoplasma papers did Eriksson, so far as we can find, acknowledge Frank's earlier usage of the term.

The term mycoplasma, used by both Frank and Eriksson to denote a cytological concept, was used next by Julien Nowak in a paper on the morphology, nature, and life cycle of the microbe of bovine pleuropneumonia to denote a taxonomic concept. Nowak wrote, in the final statement of his conclusions (translation): "The term Mycoplasma peripneumoniae seems to agree better with the nature and the morphology of the microbe." (18). In the second volume of his book Nowak, describing the bovine pleuropneumonia organism in culture, wrote (19): "The name mycoplasma seems suited both to its unusual protoplasmic nature and also to its remarkable mycelial morphology," seemingly a better description of his usage of the term than in the 1929 paper. It is possible that the description in the book was written prior to the 1929 paper or that there is a still earlier work which gives, in greater detail, the reason for his choice of the term mycoplasma. Nowak did not cite any earlier works, however, nor did he acknowledge either Frank's or Eriksson's prior use of the term.

Nowak's taxonomic usage of the term mycoplasma was noted at about the same time (1955) by Freundt, who stated that: "The conservation of Mycoplasma (as a generic term) is formally correct and hence unimpeachable and less liable to meet with criticism" (14) and by Edward, who wrote: "If the rules of nomenclature are to be strictly observed, there is no doubt that Mycoplasma is the legitimate name... All the names which might legitimately be considered are unfortunate because they suggest a relationship with the fungi. For Mycoplasma it may be claimed that it has the advantage of drawing attention to one generally accepted property of the organisms, namely, their plasticity" (2). Edward and Freundt wrote a joint paper the following year on the classification and nomenclature of organisms of the pleuropneumonia group (3).

In a preliminary statement just prior to the 1955 papers of Freundt and Edward, the Editorial Board of the International Committee on Nomenclature of Bacteria (1) noted that: "As next in priority sequence Mycoplasma apparently is, therefore, the legitimate name of the genus. It is unfortunate that it resembles the morphological designation mycoplasm (sic) once used in mycology." Freundt subsequently wrote a description and classification of $\mathrm{MyCO}$ plasmatales for the seventh edition of Bergey's Manual (15). The taxonomic usage of the term 
was approved by the Judicial Commission a year later when they issued their "Opinion 22," which failed to recognize that the term mycoplasma was "once used in mycology" (16). Thus it appears that the term mycoplasma has been adopted for taxonomic purposes without specific reference to either Frank's or Eriksson's prior usage of it as a cytological concept. This does not, however, preclude the legitimacy of any such subsequent taxonomic usage.

We thank Franz Nienhaus for his kind assistance in the translation and interpretation of the papers of $\mathrm{A}$. B. Frank and Kenneth Baker for his help and encouragement throughout this undertaking.

Address requests for reprints to: Mr.. Conrad J. Krass, Department of Plant Pathology, University of California, Berkeley, Calif. 94720.

\section{LITERATURE CITED}

1. Editorial Board. 1955. Preliminary statement. The status and synonymy of the bacterial generic name Asterococcus, Int. Bull. Bacteriol. Nomencl. Taxon. 5: 13-20.

2. Edward, D.G. 1955. A suggested classification and nomenclature for organisms of the pleuropneumonia group. Int. Bull. Bacteriol. Nomencl. Taxon. 5: 85-93.

3. Edward, D.G., and E.A. Freundt. 1956. The classification and nomenclature of organisms of the pleuropneumonia group. J. Gen. Microbiol. 14: 197-207.

4. Eriksson, J. 1896. Neue Untersuchungen über die Specialisirung, Verbeitung und Herkunft des Schwarzrostes (Puccinia graminis Pers.). Jahrb. Wiss. Bot. 29:499-524.

5. Eriksson, J. 1897a. Vie latente et plasmatique de certaines Urèdinèes. C. R. Acad. Sci. 124:475-477.

6. Eriksson, J. 1897b. Der heutige Stand der Getreiderostfrage. Ber. Dtsch. Bot. Ges. 15: 183-194.

7. Eriksson, J. 1898. A general review of the principal results of Swedish research into grain rust. Bot. Gaz. 25: 26-38.

8. Eriksson, J. 1903. The researches of Professor $\mathbf{H}$. Marshall Ward on the brown rust on the bromes and the mycoplasm hypothesis. Ark. Bot. 1: $139-146$.

9. Eriksson, J. 1910. Über die Mykoplasmatheorie, ihre Geschichte und ihren Tagesstand. Biol. Centralbl. 30:618-623.

10. Eriksson, J. 1930. Fungous diseases of plants in agriculture, horticulture and forestry, 2nd ed. (Translated by William Goodwin.) Baillière, Tindall and Cox, London.

11. Eriksson, J. and G. Tischler. 1904. Über das vegetative Leben der Getreiderostpilze. I. Puccinia glumarum (Schm.) Eriks. \& Henn. in der heranwachsen den Weizenpflanzen. Kgl. Sv. Vet. Akad. Handl. 37(6):1-19.

12. Frank, B. 1889. Ueber die Pilzsymbiose der Leguminosen. Ber. Deut. Bot. Ges. 7:332-346.

13. Frank, B. 1890. Ueber die Pilzsymbiose der Leguminosen. Landwirt Jahrb. 19: 523-640.

14. Freundt, E.A. 1955. The classification of the pleuropneumonia group of organisms (Borrelomy. cetales). Int. Bull. Bacteriol. Nomencl. Taxon. 5:67-78.

15. Freundt, E.A. 1957. Order X. Mycoplasmatales Freundt, 1955, p. 914-926. In Bergey's manual of determinative bacteriology, 7th ed. The Williams \& Wilkins Co., Baltimore, Md.

16. Judicial Commission. 1958. Opinion 22. Status of the generic name Asterococcus and conservation of the generic name Mycoplasma. Int. Bull. Bacteriol. Nomencl. Taxon. 8: 166-168.

17. Large, E.C. 1940 . The advance of the fungi. Jonathan Cape, Ltd., London.

18. Nowak, J. 1929. Morphologie, nature et cycle èvolutif du microbe de la pèripneumonie des bovidès. Ann. Inst. Pasteur 43: 1330-1352.

19. Nowak, J. 1930. Documenta Microbiologica. Zweiter Teil: Pilze und Protozoen, p. 149. Gustav Fischer, Jena.

20. Ward, H. M. 1904. On the histology of Uredo dispersa Erikss. and the "mycoplasm" hypothesis. Phil. Trans. Roy. Soc., London, Ser. B. Biol. Sci. 196: 29-46. 